\title{
IVAN VYRYPAYEV IN SLOVAKIA
}

\author{
NADEŽDA LINDOVSKÁ \\ Institute of Theatre and Film Research, \\ Art Research Centre of the Slovak Academy of Sciences, Bratislava
}

\begin{abstract}
Theatre plays by Ivan Vyrypayev, Russia's foremost and most influential contemporary playwright, are frequently staged not only in Russia, but also abroad, several plays have even been written on demand of European theatres. Vyrypayev is a very special and in many ways antipodal author. On the one hand, he bases himself upon the Russian cultural tradition, while engaging in a critically tuned dialogue with it. He introduces new staging techniques and new themes to theatre production, which respond in a very sensitive way to the current state of European civilisation and to the situation of man in the world affected by the crisis of values. Slovak theatre became first aware of his work in the early $21^{\text {st }}$ century. Since 2004, up until now, his plays Sny [Dreams], Iyul [July], Pyanye [The Drunks], Ilyuzii [Illusions], Letniye osy kusayut nas dazhe $v$ noyabre [Summer Wasps Bite Us Even in November], Nevynosimo dolgiye obyatiya [Unbearably Long Embraces] have been staged in Slovakia. Initially, it was the Slovak independent theatre expressing its interest in Vyrypayev's texts, but very quickly, mainstream theatres followed suit. They have crossed generational barriers, and in the staging of his plays, the actors of young and oldest generations deliver remarkable performances. In a country in the heart of Europe, the poetics of an author who creates on the borderline between the East and the West, has resonated markedly well with the audiences. The theme of the relationship between Slovak theatre and Ivan Vyrypayev's dramatic work remains open, whereby the presented study records and reflects on the current situation.
\end{abstract}

Key words: contemporary Slovak theatre, Russian new drama, Ivan Vyrypayev

\section{The Russian Playwright Ivan Vyrypayev}

Russian art enjoys a great reputation abroad and attracts attention thanks to a number of exceptional creators and remarkable works of art. Several phenomena of Russian culture have become literally an export commodity. This includes theatre art and its tradition, acting techniques and direction staging techniques, especially Stanislavsky system of acting, the creative heritage of the Moscow Art Theatre, Vsevolod Meyerhold theatrical discoveries, and the work of Anton Chekhov in the field of drama literature. In the post-Soviet period, Ivan Vyrypayev's theatre plays have become such export commodity, spreading the reputation of Russian theatre and drama abroad after 2000.

The playwright Ivan Vyrypayev is an extremely original and, in a sense, contradictory personality. Originally an actor and stage director, he has progressively profiled himself primarily as a playwright and, occasionally, he would take up successful film projects. He was born in 1974, in Irkutsk, a large Siberian town on Lake Baikal. His life and the life of his generation were affected by a sweeping historical turning point - the collapse of a superpower that was his home, the demise of the Soviet Union and its political system, a sweeping transformation of society, and an ensuing series of dramatic social upheavals. Vyrypayev grew up in the Soviet era, he experienced pioneer childhood and socialist schooling, he witnessed Brezhnev's social stagnation and experienced Gorbachev's perestroika during puberty. He grew up 
in a difficult period of the so-called wild 1990s, when Russia fell into a huge political, economic and value crisis after the collapse of the Soviet Union. He studied acting and for a short time, he worked in Magadan and Kamchatka, and together with his friends, he endeavoured to establish his own theatre in Irkutsk. He began writing his early texts, but his hometown did not respond positively to his creative ambitions and experiments, which made him move to Moscow. In Russia's capital, an unknown provincial young man became a theatrical sensation. His Kislorod [Oxygen] (2002), thanks to its originality and a poetic language, attracted a wide audience and experts. The play was understood as a manifesto of a new generation of young Russians, coveting for a free and full breath of new life. The production of this play, in which the author personally performed, toured the entire land and it received many invitations to foreign theatre festivals, including festival Divadelná Nitra (International Theatre Festival Divadelná Nitra), Slovakia. Vyrypayev continued to write and soon, his name was among the symbols of the new Russian $21^{\text {st }}$ century drama, both nationally and internationally.

The playwright often gives interviews and continues to surprise with paradoxical statements. At the beginning of his career, he would regularly repeat that, in fact, he did not like theatre, although he started out as an actor and he added stage directing from which he graduated in Moscow. During his eventful and prolific years after leaving Irkutsk, he was awarded numerous national and international theatre and film prizes, he collaborated with several theatres, he shot several films and wrote a novel. He travelled the world and was exposed to other cultures and even began practicing yoga. He moved towards Hinduism and became a vegetarian. He claims to be cosmopolitan of Russian origin. Currently, he lives and works in both Russia and Poland, where he has a family, and writes plays on demand for European theatres. For a long time, he was known as a proponent of the aesthetics of postmodernism but now he distances himself from it. And he no longer claims that he is not fond of theatre.

Vyrypayev constantly combines the work of a playwright with that of a director and an occasional actor. When it comes to his writing theatre plays, he does not belong to any school ${ }^{1}$, he has never pursued formal studies in creative writing. He is a self-made man. He has created his own original and for Russian drama in many ways unusual authorial style. He represents a new generation of Russian society, theatre and of culture which approaches the art, life, and homeland in a novel way and establishes a new relationship with its cultural traditions.

Over twenty years of working in the theatre, several Ivan Vyrypayev's views have undergone a change. Initially, he presented himself as an opponent of stories, only to change his mind later on, and eventually he turned into a quirky theatrical narrator who is fond of using the epic principle and creatively plays with the potential of a monologue. He has programmatically refused to comment on politics because he is particularly interested in reflecting on the spiritual path of the development of human civilisation. However, he has written an extensive letter in support of director Kirill Serebrennikov, which reflects on the $20^{\text {th }}$ century totalitarian systems, on their

${ }^{1}$ On the verge of the $20^{\text {th }}$ and $21^{\text {st }}$ centuries, several Russian playwrights acclaimed reputable playwrights, such as Viktor Rozov, Lyudmila Petrushevskaya, Nikolai Kolyada, Michail Ugarov, Elena Gremina, to be their teachers. 
repercussions in the present, and on the way of changing the Russian power apparatus. $^{2}$

Thirty-year-old Vyrypayev opposed the staging of Chekhov's plays. He admitted that he was fond of Chekhov's plays, but he believed that this classic had nothing to say today, as he was outdated. More than a decade later, as a forty-year-old, he directed Chekhov's Uncle Vanya in Warsaw (Teatr Polski, 2017), and the production received a great response. For the time being, we can only rhetorically ask how the work of the playwright Vyrypayev will be affected by a theatre dialogue between director Vyrypayev and the works of Anton Chekhov. In the meantime, Vyrypayev gives a laconic reply to the question about his favourite $20^{\text {th }}$ century playwrights: Edward Albee, Tom Stoppard, and Arthur Miller. ${ }^{3}$

As a beginning theatre professional, Ivan Vyrypayev was greatly critical of Russian theatre. He demanded its modernisation and he personally advocated a pursuit of new ways in theatre and in drama. At present, his views on Russian theatre are more subtle, he shows more understanding for its specificities and traditions, and he is more appreciative of the standards of Russian acting. He claims to be a proponent of an essential pursuit of Russian theatre art to raise fundamental questions of human existence. He claims he remains to be a Russian artist, his work is influenced by Russian mentality, its culture and by its belief system, although in the recent decade, the characters in his plays have been given non-Russian names. ${ }^{4}$

Ivan Vyrypayev's authorial poetry is characterised by a specific, fascinating, literary language in which colloquial expressions, sometimes vulgarisms, naturally blend in with poetic metaphors, archaic words and phrases without triggering a feeling of obsolescence. The characters' speech often gushes like a torrent, like a dramatic poem with plenty of allusions and even biblical references. Irony and humour help the author bring ease to serious topics and not to slip into exaggerated pathos. He consciously divides his plays into two groups: the first group are plays, in which he approaches the viewer through narration and which are distinctly monological (e.g, Kislorod [Oxygen], Ilyuzii [Illusions], Nerynosimo dolgiye obyatiya [Unbearably Long Embraces]), and the second group are plays which are more traditional, their characters communicate with each other through a dialogue Pyanye [The Drunks], Letniye osy kusayut nas dazhe v noyabre [Summer Wasps Bite Us Even in November], etc.). Vyrypayev portrays a dissonant world in which almost everything is relative, shaky, changeable, and illusory. People who live in it do not strive to mend it, they are deranged and disoriented, desperately seeking foundations on earth and in outer space. They communicate with the universe to find answers to a plethora of everyday questions of human existence. The playwright provokes a dialogue with the audiences, he

${ }^{2}$ VYRYPAYEV, I. Открытое письмо драматурга и режиссера Ивана Вырыпаева в поддержку Кирилла Серебренникова [An open letter of playwright and stage director Ivan Vyrypayev in support of Kiril Serebrennikov, 25 August 2017]. [online]. [cit. 10 May 2019]. Available at: https://telegra.ph/Otkrytoe-pismodramaturga-i-rezhissera-Ivana-Vyrypaeva-v-podderzhku-Kirilla-Serebrennikova-08-24.

${ }^{3}$ VYRYPAYEV, I. - VERESKOV, S. В России люди приходят в театр за смыслом жизни [In Russia, people seek purpose of life in the theatre, an interview], 1 December 2018. [online]. [cit. 11 May 2019]. Available at: https://www.elle.ru/celebrities/interview/ivan-vyrypaev-v-rossii-lyudi-prihodyat-v-teatr-zasmyslom-zhizni-id6801722/.

${ }^{4}$ VYRYPAYEV, I. - CHERNYAKOVA, S. Ivan Vyrypayev: Все мои пьесы очень русские [All my plays are very specific to Russian society, an interview], 11 December 2018. [online]. [cit. 20 May 2019]. Available at: https://snob.ru/entry/169432. 
urges viewers to reflect on the dilemmas presented through characters and storylines. This he understands to be his mission, and the content and form of the work are subordinated to it. Some of his texts resemble theatrical sermons in which he skilfully avoids forthright didacticism. He alternates God-seeking with blasphemy, and he outrightly claims that he does not believe in the existence of God. ${ }^{5}$ Several of his plays have been perceived as an opinion and artistic manifesto. They are characterised by a surprising content, an original form, and by accentuating the word and by an urge to create a new kind of acting.

Ivan Vyrypayev, despite his ever-changing views concerning his relationship with Russia and with the world, with the traditions of Russian theatre, religion, and so on, has maintained a striking continuum of his creation. He consistently develops the previously established authorial practices. Equally, he insists that his plays be staged as originally written, without modifications and rewriting, following authorial instructions. In theatre, the playwright Vyrypayev prefers the dictate of the author of a dramatic text over the dictate of the theatre director. He reminds the actors to avoid emotional identification with their characters and with the storyline, he urges them to keep distance and to perform in a matter-of-fact way. Along with other authors, representatives of European contemporary drama, he strives to shape a new theatrical language. For Slovak theatre, the encounters with Ivan Vyrypayev have, in a way, served as a school of new theatre approaches.

\section{Early Contacts of Slovak Theatre with the Work of Ivan Vyrypayev}

Slovak theatre first took note of Ivan Vyrypayev's plays at the outset of the new millennium, when he was just one of many interesting young Russian playwrights. The first to have shown interest in his work were young independent theatre-makers who approached it with a feeling of generational affinity and it were mostly young theatre critics responding to their creative acts. The former and the latter approached Vyrypayev as their generational ally having a similar aesthetic and social perception of art and of our time and who, in a sense, shared experience similar to that of the people in other post-socialist countries. On 8 February 2004, Vyrypayev's early play Sny [Dreams] directed by Marián Amsler was premiered in Studio 12 in Bratislava. The translation of Sny [Dreams] was published in 2000. The Slovak text version was developed by Romana Maliti, the would-be devoted translator of Ivan Vyrypayev's plays in Slovakia. ${ }^{6}$

In September 2004, International Theatre Festival Divadelná Nitra featured in its programme a production of the Moscow theatre Teatr.doc based on the play by Ivan Vyrypayev Oxygen, directed by Viktor Ryzhakov. The author attended Divadelná Nitra Festival and he was one of the performers. This, in fact, was the first time the playwright visited Slovakia. On this occasion, Romana Maliti translated Oxygen into

${ }^{5}$ VYRYPAYEV, I. - IVANOVA, O. Я ничего не могу попросить у Бога, потому что я считаю, что его нет [I cannot ask God for anything, as to my mind he does not exist, an interview], 15 December 2014 . [online]. [cit. 20 May 2019]. Available at: https://okolo.me/2014/12/ya-nichego-ne-mogu-poprosit-u-bogapotomu-chto-ya-schitayu-chto-ego-net/.

${ }^{6}$ Romana Štorková Maliti has translated the following Vyrypayev's plays into Slovak: Sny, Kislorod, Iyul, Tanec Deli, Pyanye, Letniye osy kusayut nas dazhe v noyabre, Nevynosimo dolgiye obyatiya [Dreams, Oxygen, July, Delhi Dance, The Drunks, Summer Wasps Bite Us Even in November, Unbearably Long Embraces]. 
Slovak. Regrettably, the play, which started a successful career of the Russian playwright back home, did not resonate in Slovakia. The unique production-concert Oxygen was given a mediocre reception on the part of Slovak audiences at the Divadelná Nitra Festival. Four years on, International Theatre Festival Divadelná Nitra 2008 featured another production by director Ryzhakov from Moscow based on the text July by Ivan Vyrypayev. It was produced in the young Praktika (Practice) Theatre in Moscow which focuses on contemporary Russian and world drama. The play July is a remarkable monodrama, a shocking monologue of a killer and cannibal who, according to the author's intention, has to be rendered by a woman. The fragile, beautiful, young Moscow actress Polina Agureyeva coped with this task brilliantly. Her performance in an unusual monodrama was highly rated, and the play July, as well as its production, raised a much keener interest than Oxygen. In 2010, its disturbing text saw its Slovak launch, again in Studio 12 in Bratislava, directed by a young theatre director Alena Lelková.

Both productions, Dreams and July, were staged by the Slovak independent theatre scene. Although their staging styles were significantly different, they shared certain common features, particularly their approach to the text. In both projects, staging teams were focused on authorial theatre. Vyrypayev's plays were a source of inspiration for their personal and creative narrative.

This was especially patent in the staging of Dreams. The play was written in the early days of Ivan Vyrypayev's creation. In it, he mused over the fate of his contemporaries in Irkutsk, many of whom succumbed to drug addiction or became HIV positive at the turn of the $20^{\text {th }}$ and $21^{\text {st }}$ centuries. It was a peculiar requiem for their unfulfilled dreams of a meaningful life, of beauty, love, faith and of harmony, but also a requiem for fears that tied their hands and that appeared on the borderline between life and altered state of consciousness. Director Marián Amsler sidelined the tragic theme of drug addiction, he interpreted Vyrypayev on the basis of his experience with the staging of gentle and poetic plays by the Russian playwright Olya Mukhina who professed her Chekhov inspirations. Amsler approached Vyrypayev as part of a young Russian drama, as a companion to Mukhina (the playwright dedicated Oxygen to Mukhina), and this perception has become a determining factor for his production of Dreams. He modified and amended Vyrypayev's text and linked it with the citations and paraphrases from Chekhov's Three Sisters, where the youngest sister dreams of a life fulfilled with a beneficial job, but soon she is overwhelmed by a feeling of disillusionment over real-life and monotonous employment. The director incorporated a Chekhovian motif of nostalgia for a better life in his production. A musical leitmotif of the production was the famous Russian romance about love and passion Ochi Chernye [Dark Eyes] in a folklore arrangement and in female interpretation. The romance epitomised the theme of Russia and Russianism, which was the only unambiguous reference to the country of origin of the author and of his characters. The intimate acting space was surrounded by spectators on two sides, and the actors were in close proximity to the audience, which enhanced a sense of interconnection and belonging.

Bratislava theatre producers shared the moods, feelings, dilemmas and thoughts vital for their generation of twenty-year-olds with their audiences. Vyrypayev's text was supplemented by their own words and they became his collective co-author. Amsler retained the basic composition of the text, divided by the theme of each 


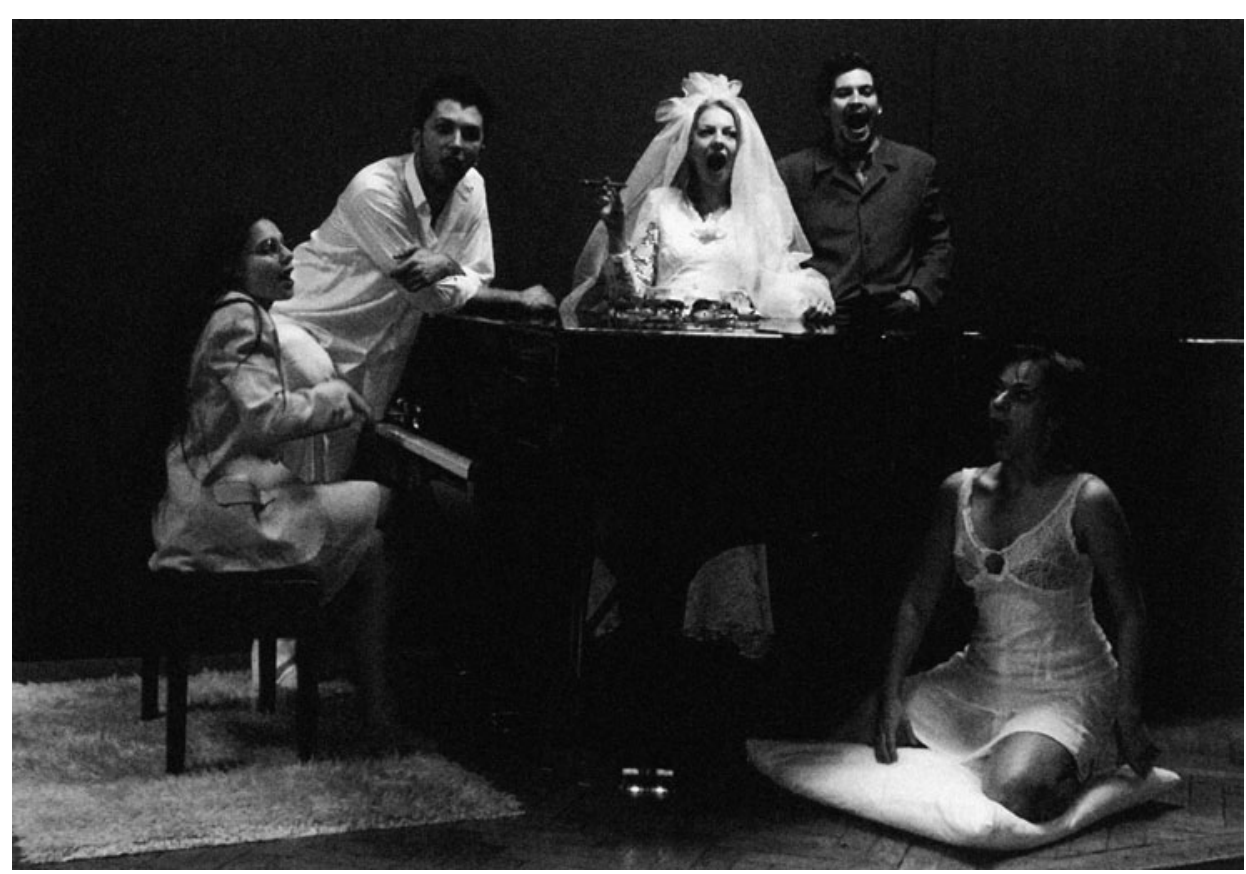

Ivan Vyrypayev: Dreams. Studio 12 Bratislava, premiered on 8 February 2004. Renáta Ryníková (A Girl with brown saliva), Viktor Horján (A Boy who is cold all the time), Anita Szvrcseková (A Girl with a pregnant belly), Marián Balážik (A Boy with a stammer), Romana Maliti (A Girl with dreams). Direction Marián Amsler. Theatre Institute archives.

dream. He extended the characters' narratives by the personal confessions of young actors and actresses (three girls and two boys) performing in the production. They connected up with the theme of dreaming, creating an intimate atmosphere of an intimate conversation of a bizarre group of friends about their basically lonely desires, problems, experiences, their search for faith and for the purpose of life. Their talk was funny and lyrical, ironic, embarrassing, sad and witty at times. It was performed in a way that evoked authenticity and aroused the audience's empathy. When it comes to critical reflection, mostly generation-close reviewers gave feedback on the production. They rated Ivan Vyrypayev's play highly and also its staging that was built on the borderline between seriousness and comicality. The young drama critic Martina Vannayová noted that under Marián Amsler's direction the text "becomes a black grotesque, a nightmare, in which characters try to come closer to each other, but this only sets them completely apart."

The production of July (premiered on March 29, 2010), was a female independent project that ensued out of a collaboration between two strong personalities - director Alena Lelková and dancer and performer Petra Fornayová. At the time of the premiere, they were both in their thirties. They did not intend to replicate Viktor

${ }^{7}$ VANNAYOVÁ, M. Sny betónových sídlisk [The Dreams of Concrete Housing Estates]. In Divadlo $v$ medzičase, 2004, Vol. 9, Issue 1 - 2, p. 6. 


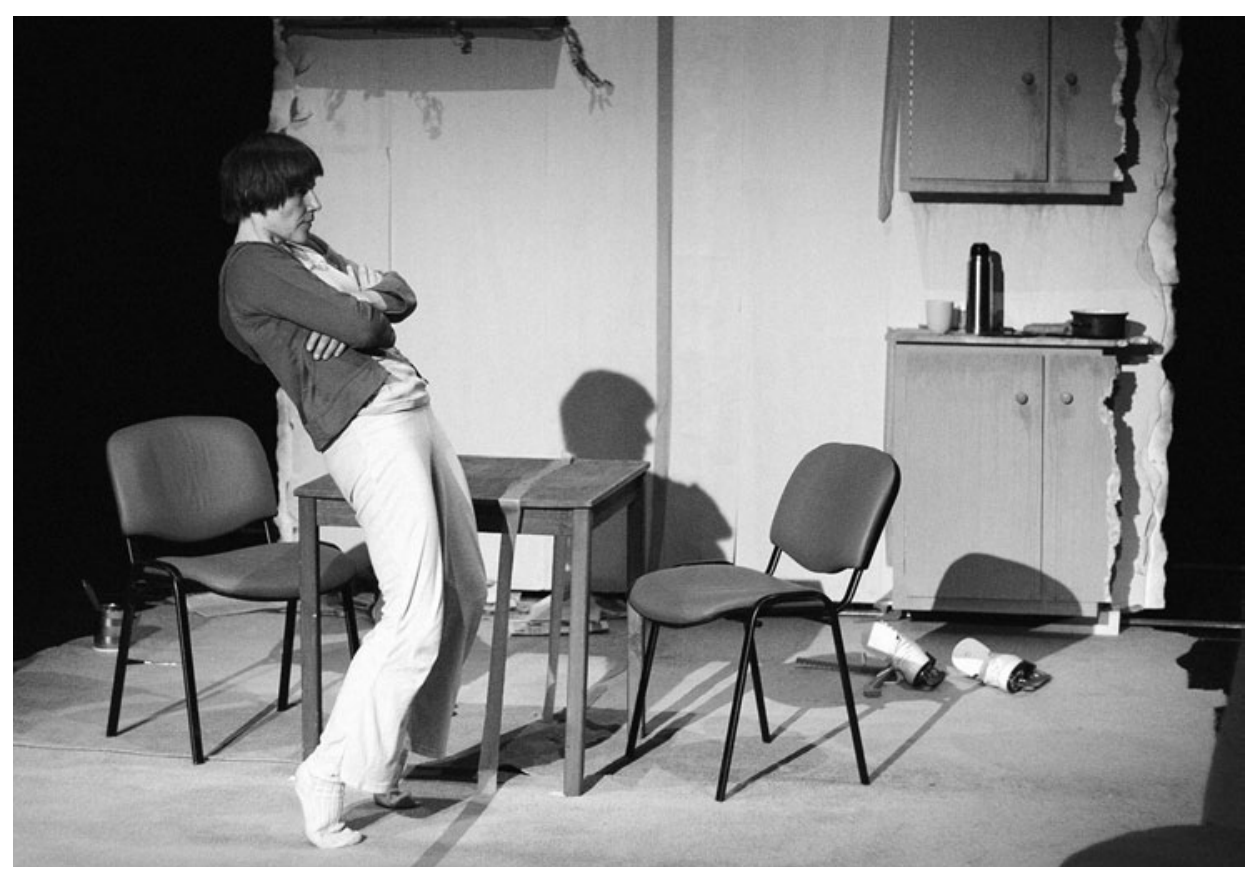

Ivan Vyrypayev: July. Studio 12 Bratislava, premiered on 29 March 2010. Petra Fornayová. Direction Alena Lelková. Photo by Radana Hromníková. Theatre Institute archives.

Ryzhakov's production featured at Divadelná Nitra Festival 2008, simply for the fact that Petra Fornayová, unlike the subtle, elegant and sophisticated Moscow actress, was an utterly different type of woman and, together with the director, she came up with a unique idea of the interpretation of the monologue of a sixty-year-old killer. Compared to the aesthetically laconic production of Ryzhakov, they moved the text from an intellectual pedestal to an ordinary environment of a dilapidated flat with a kitchen unit falling apart. A man's monologue, uttered by a woman, was heard in parallel with doing the daily household chores, such as food preparation, the pealing of carrots, and so on. The slow pace of the production enhanced the feeling of frustration over the ordinariness of life. As noted by a reviewer, the woman, impersonated by Petra Fornayová, lived a virtually "apocalyptically" lonely life without love in her dilapidated flat. ${ }^{8}$ She became the main character of the play and the story about a serial killer became "the story of a woman and her relationship with this man" to whom she almost voluntarily surrendered her body and life. In the finale, her world underwent an awesome transformation, and by using projection technology, ordinariness vanished under big petals of roses. A rustic ornament covered up the

${ }^{8}$ MOŠKO, M. Symbolika na premýšlanie [Symbolics to Think about]. In Monitoring divadiel na Slovensku, 29 March 2019. [online]. [cit. 11 April 2019]. Available at: https://www.monitoringdivadiel.sk/recenzie/ recenzia/symbolika-na-premyslanie/.

${ }^{9}$ TARBAJOVSKÁ, L. Ivan Vyrypajev: Júl [Ivan Vyrypayev: July]. In Vlna, 2011, Vol. 13, Issue 48, p. 157. 
decrepit walls and eventually ingested the woman. Her eyes were glowing, she was no longer wearing a stretched-out T-shirt and an old tracksuit; she was dressed up in a rose-covered ladies' dress. Tenderness blossomed out of the bloody horror of homicidal acts. Such a contrasting finale corresponded to the internal dichotomy linking up cruelty and poetry in Vyrypayev's monodrama July.

Again, the critics covering the production mostly belonged to the younger generation. Although the text was rated highly, the performance was criticised for poor communicativeness and several segments were labelled as boring. The critics were very particular about the actors' interpretation of the play. The theme became central to a comprehensive analysis by the critic Miroslav Zwiefelhofer, who pointed out that the major problem of the Bratislava production of Vyrypayev's monodrama lied in the wrong direction and consequently acting interpretation of the play. He opposed the actress emotionally identifying herself with the narrative, in order to impersonate her character on stage. In his opinion, illusive stage design, anchoring the text in the real world of an individual living on the edge of society, were in contrast with Vyrypayev's unconventional text. Overall, it turned out to be a boring monodrama of a traditional realistic type. Zwiefelhofer rightly pointed out that in July, the author was more radical than Brecht in urging the performer to distance herself from the character. "July is a play about an actress who interprets Piotr's thoughts, it is not the story of Piotr (...) and simply should not be staged using conventional theatrical language 110 , it should be looked upon from the performative theatre perspective.

Seeking an appropriate theatrical language that would facilitate the stage production of Ivan Vyrypayev's plays posed a challenge for Slovak theatre and it took several years before it was able to cope with it.

\section{Vyrypayev in Slovak Theatre after 2010}

Slovakia embarked on a creative dialogue with the author thanks to independent young theatre makers. However, Marián Amsler and Alena Lelková, directors of the productions of Dreams and July, did not consider staging other Vyrypayev's plays. It turned out that Vyrypayev's texts required a more rigorous adherence to authorial instructions and a specific actor's approach. After several years of slackened interest in the creation of the Russian playwright, the situation changed in 2014. Since then, Slovak theatres have staged several Vyrypayev's plays and in 2016, an omnibus volume in Slovak of Ivan Vyrypayev's plays was published. In May 2016, he visited Slovakia in his capacity of the patron of the New Drama Festival.

Following the early attempts of independent theatre to stage his plays, reputable mainstream theatres undertook to produce Vyrypayev's plays, including the most prestigious one - the Drama Ensemble of the Slovak National Theatre. The fact that in recent years, the reputation of Ivan Vyrypayev as an artist has risen dramatically, has ranked him among the most acclaimed representatives not only of Russian but also of European modern drama to say the least. However, the main and determining factor for a successful staging of Vyrypayev's plays in Slovakia after 2010, was a theatre

${ }^{10}$ ZWIEFELHOFER, M. Júl Ivana Vyrypajeva - dráma vraha Piotra alebo výstup jednej herečky? [July by Ivan Vyrypayev - the Drama of the Murderer Piotr or a Performance of an Actress?] In kød, 2010, Vol. 4, Issue 5, p. 19. 


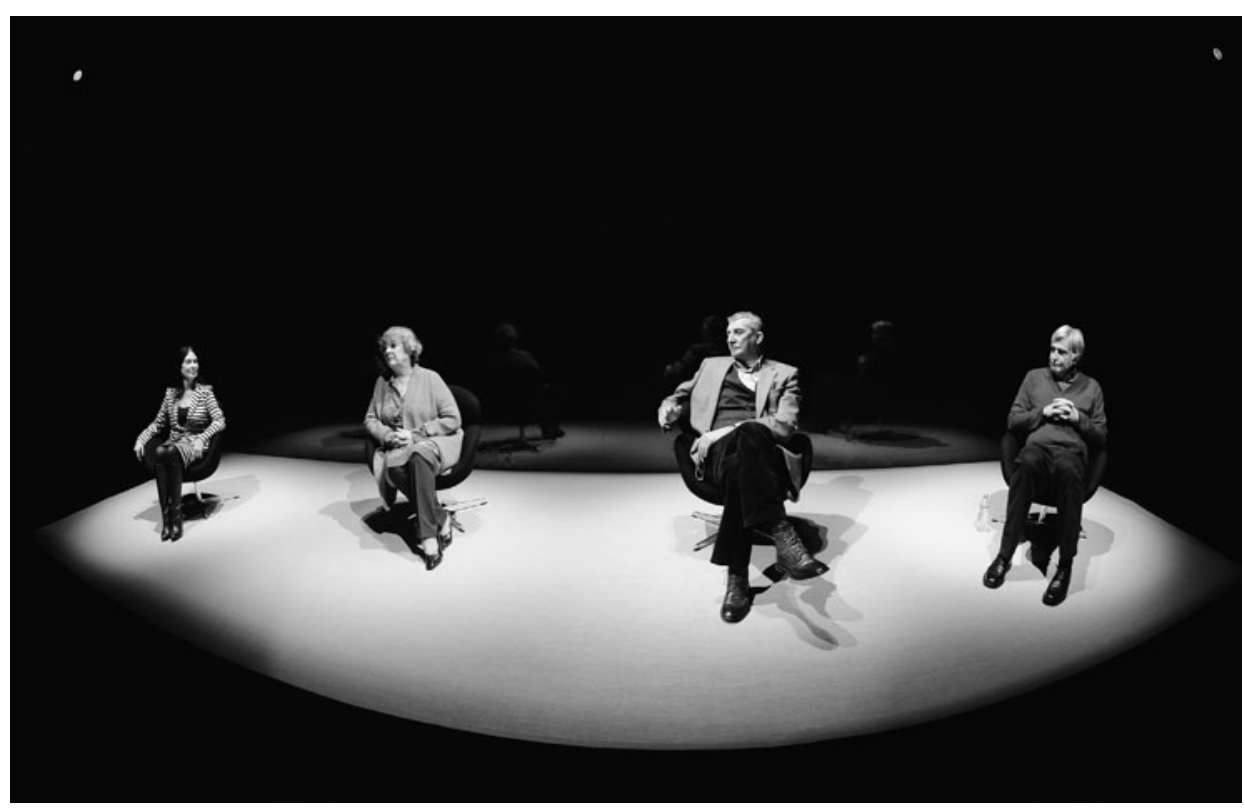

Ivan Vyrypayev: Illusions. Slovak National Theatre, premiered on 23 January 2014. Zuzana Kocúriková (The First Woman), Božidara Turzonovová (The Second Woman), Martin Huba (The First Man), Dušan Jamrich (The Second Man). Direction Eduard Kudláč. Photo by Branislav Konečný. Slovak National Theatre archives.

professional who took a genuine fancy to his creation and was able to make sense of it. This man was theatre director Eduard Kudláč, the Russian playwright's contemporary (he is two years older than Vyrypayev), whose home stage is Mestské divadlo Zilina (City Theatre Žilina).

Kudláč is a contemplative type of director-philosopher. He is not averse to entertainment repertory and he is good at it, but among his most notable artistic achievements are his directions of contemporary, especially of German drama, and the stage adaptations of classic prose, whereby he would frequently turn to the works of Feodor Dostoievsky. Kudláč would not hesitate to connect the theatre and epics, or to employ frequent and exacting monologues. He is fond of theatre, in which emphasis is put on the word, on its content and on the overcoming of both human and artistic taboos. He has developed a peculiar theatrical language, in which refined and utterly minimalist visuality is associated with the same minimalist, yet, elaborate style of acting. Kudláč is also a director-analyst, who creates terse, thought-out, meditative productions emanating a dense emotional atmosphere. Ivan Vyrypayev offered him exactly the type of drama, which reaches out by its psychoanalytical dive and by philosophical focus, narrativeness and provoking aesthetics. Vyrypayev's plays are close to Dostoievsky by their ruthless and at the same time compassionate unravelling of human nature. This is yet another overlap between the Russian author and the Slovak theatre director which facilitates understanding.

Kudláč has directed three plays by Vyrypayev, whereby Illusions have been staged twice by him. It was staged for the first time in 2014, in the capital city of Slovakia, 
Bratislava, in an intimate space of the Drama Ensemble of the Slovak National Theatre (SND). Ivan Vyrypayev produced Illusions at Praktika Theatre in Moscow (he even performed in the production) as a story of two befriended old couples whose lives were drawing to a close, performed by four young actors. However, Slovak National Theatre decided to base the staging on the mastery of the theatre's oldest generation of actors. The play Illusions provided four acting opportunities, whereby one female part was alternated. The best quartet of actors born in the 1940s was present on the stage, the great personalities and literally legends of Slovak drama art: Božidara Turzonovová, Emília Vášáryová alternated by Zuzana Kocúriková, Martin Huba, and Dušan Jamrich. The performance they delivered under Eduard Kudláč's direction was rightly referred to by reviewers as a stunning "concert of actors." The production triggered a positive response across the generations, both beginning and experienced theatre critics, and also the wider Slovak culture community reflected on it. Everyone was charmed by the play's unusual content and language, by its final stage form, despite the fact that the Slovak audience is not accustomed to going to the theatre to listen to a vast body of text (unlike the Russian or French audiences); typically, the Slovak viewer prefers watching action on stage. Illusions were a static production, in which two women and two men remained seated during the entire performance on an empty stage and facing the auditorium, they shared the stories of four eightyyear-old Americans who flashed back on their lives and on mutual relationships. The fabric of monologues and additional lines gradually revealed that their harmonious marriages were probably an illusion and there were secret love triangles in their amicable set-up of four. The production made do without visual or sound effects. Music was only heard in final silence, when actors went quiet. It was then the dark back space of the stage was illuminated, emerging from behind the performers' backs. It called to mind an old, abandoned place of one-time meetings of married couples, now covered with the rust of time ${ }^{11}$. This symbolic image was a nostalgic visual endpoint of a performance clearly dominated by word magic and by sophisticated text, breaking the traditional perception of drama, dialogue, dramatic storyline, suspense, and of conflict.

As noted by an experienced critic, in his play, the young Russian playwright demonstrated that our perception of what is possible and impossible in theatre and drama, was but an illusion. ${ }^{12}$ Several reviewers referred to the text as being unconventional and risky for production. ${ }^{13}$ Slovak acting legends performing in Illusions admitted that in fifty years of work with the theatre, they had never been confronted with such type of text. Despite that theatre professionals and the audiences fell in love with the play ${ }^{14}$ for its universal timeless human values, the depth of ideas, for an honest concern for human relationships, for thematising human need of love and of love-sharing, for its quest for the truth of life, which - as it seems - is never

${ }^{11}$ It is Eva Kudláčová-Rácová to be given credit for the scenic design concept and the costumes in Eduard Kudláč's productions, including the productions of Ivan Vyrypaev's plays.

${ }_{12}$ POLÁK, M. Diváka vtiahli na javisko [The Viewer Was Drawn onto the Stage]. In Literárny týždenník, Vol. 27, Issue 5-6, p. 7, 12 February 2014.

${ }^{13}$ BEŇOVÁ, J. Všetci o tom chceme hovorit', ale nik nemá odvahu [We All Want to Talk about It, But No One Has the Courage]. In kød, 2014, Vol. 8, Issue 3, p. 13.

${ }^{14}$ By end of 2018/2019 season, the production had many re-runs and it will remain in repertory for the next theatre season. 


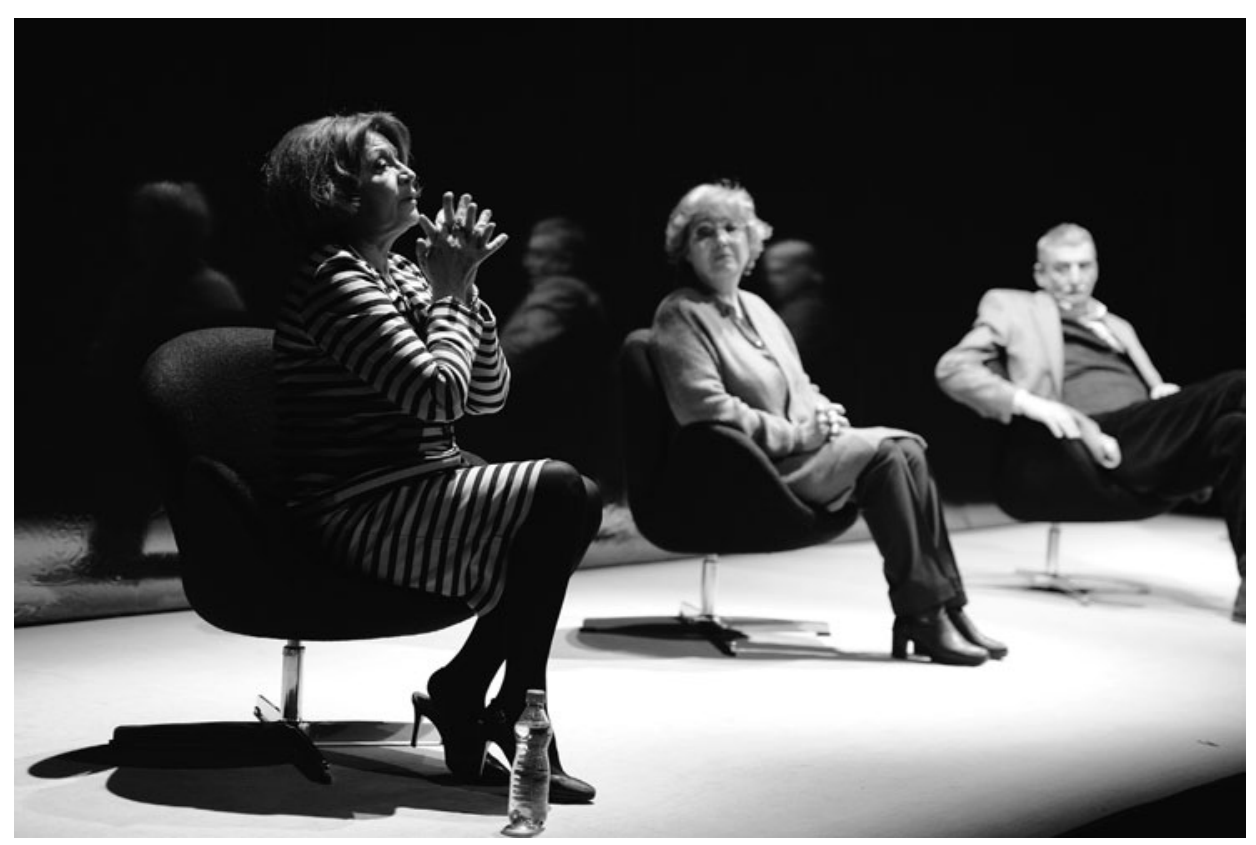

Ivan Vyrypayev: Illusions. Slovak National Theatre, premiered on 23 January 2014. Emília Vášáryová (The First Woman), Božidara Turzonovová (The Second Woman), Martin Huba (The First Man). Direction Eduard Kudláč. Photo by Branislav Konečný. Slovak National Theatre archives.

certain and instead of which illusions prevail ever too often. A component part of the narrative about the disillusionment with life and men's and women's lies was capturing their desperate quest for a stable point in a constantly changing universe. Their stories were, de facto, our stories, their hopes and dilemmas concerned each individual on the stage and in the auditorium. The play also captured attention by Ivan Vyrypayev's ability to communicate via a language in which ordinariness goes hand in hand with poetry, lyricism with irony, an experience of ordinariness and philosophical depth are encrypted in it, and it conveys emotions and tension, smiles and sadness. Director Kudláč approached the text, its content and the depth of words with the highest level of respect and equally, he greatly appreciated the creative maturity of Slovak prominent actors. Thanks to their virtuosity, each rerun unfolded as a fascinating dialogue with the audience about the fundamental existential questions, as food for thought. "This theatre defied all laws of the theatre. (...). And yet, it was drama. And it was a shock, although creative professionals shunned live cohabitation or bad language. We have been struck by the authenticity of the theatre (...). It had to work somehow like this in ancient Greece. Theatre is an illusion, but it is an illusion that nurtures the truth about us", commented on the production the well-known Slovak writer (hexagenerian) Daniel Hevier. ${ }^{15}$

${ }^{15}$ HEVIER, D. Ked' sa žije z ilúzie [When People Live on Illusion]. In Sme, Vol. 22, Issue 23, p. 12, 29 January 2014. 


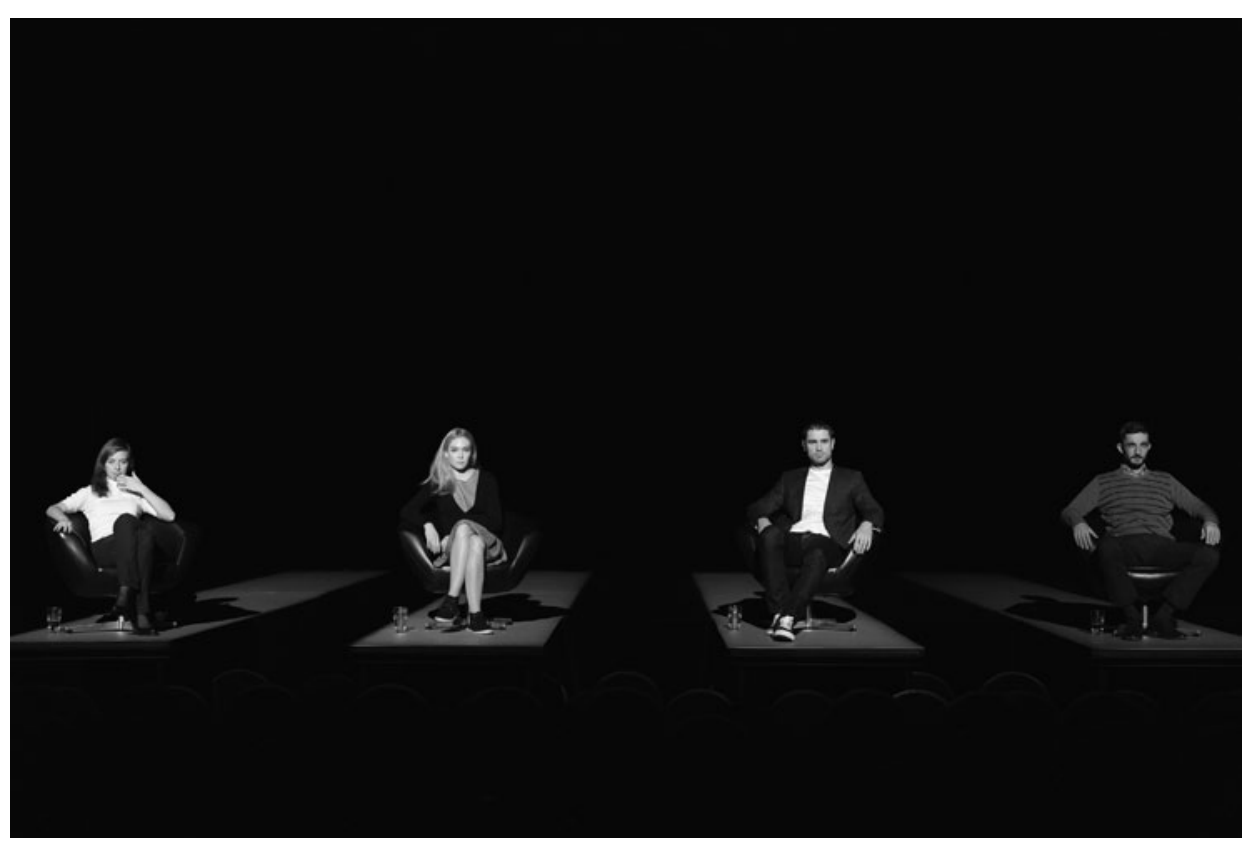

Ivan Vyrypayev: Illusions. City Theatre Žilina, premiered on 14 November 2015. Iveta Pagáčová (The First Woman), Monika Havasi (The Second Woman), Ján Dobrík (The First Man), Michal Režný (The Second Man). Direction Eduard Kudláč. Photo by Eduard Kudláč. City Theatre Žilina archives.

Following this particularly successful production, Eduard Kudláč, together with the actors from Žilina, staged Vyrypayev's play The Drunks, (premiered on 5 December 2014). They were so much intrigued by the creation of the Russian playwright that they approached Kudlác to stage Illusions with them. In less than two years after the play was first staged by SND, Illusions were premiered by City Theatre Žilina. In the second version of this play the director, in line with Vyrypayev's initial requirements, cast thirty-year-old actresses and thirty-five-year old actors, but otherwise maintained his original direction concept. Again, he avoided visual and sound effects, the performers were seated in chairs, facing the audience, focusing attention on the text and on establishing a dialogue with the audiences. A successful repertory title was produced in this Slovak region, however, theatre critics, when comparing Źilina production of Illusions with Bratislava Illusions, favoured the Slovak National Theatre production. They argued that Žilina actors proved inconsistent in the interpretation of the text: "As if the creators gave up on the overriding initial principle, i.e. an actor is not a character, he/she just gives an account of what happened, and they forgot to balance out deep actors' emotions. An enormous effort of the actors to tell the story in a most appealing and most emotional fashion ran counter to the dramatic form. ${ }^{\text {"16 }}$ For young actors who did not have life and artistic experience anywhere near to the

${ }^{16}$ BEŇOVÁ, J. Ako v Žiline podl’ahli ilúziám [How People in Žilina Give into Illusions]. In Monitoring divadiel na Slovensku, 23 April 2016. [online]. [cit. 12 April 2019]. Available at: https://www.monitoringdivadiel. sk/recenzie/recenzia/ako-v-ziline-podlahli-iluziam/. 


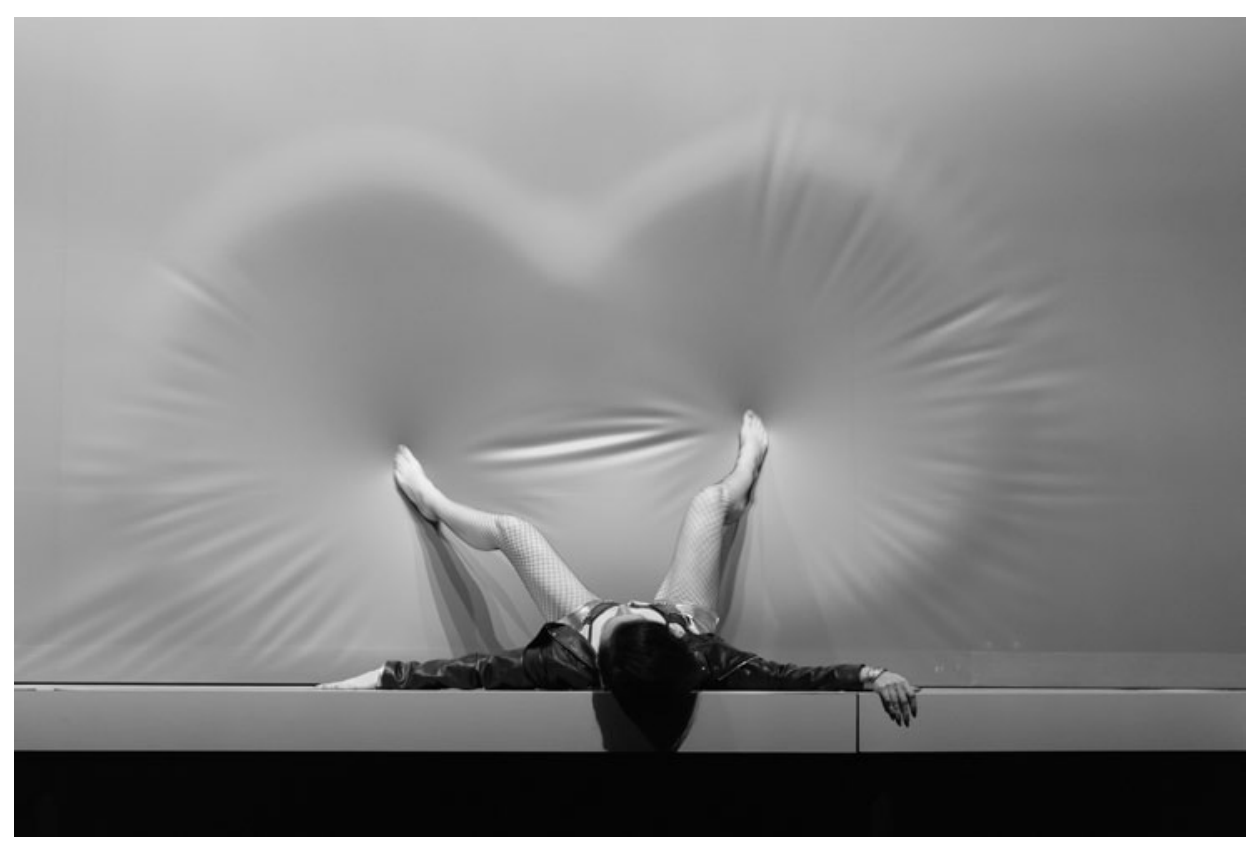

Ivan Vyrypayev: The Drunks. City Theatre Žilina, premiered on 5 December 2014. Iveta Pagáčová (Róza). Direction Eduard Kudláč. Photo by Eduard Kudláč. City Theatre Žilina archives.

experience of the acting legends of the Slovak National Theatre, Illusions proved a big challenge. They succumbed to an emotional identification with their characters, thus breaking the principle of impartial narration and emotional distance. On the other hand, they enriched the production by the energy and optimism of youth.

As mentioned above, Illusions were a second encounter of Žilina actors with Vyrypayev's drama creation. It was preceded by the production of The Drunks. After the success of Illusions staged by the Slovak National Theatre, the director did not contemplate to programmatically continue putting on stage Vyrypayev's plays. When he was trying to find a comedy that would suit City Theatre Žilina, he researched contemporary drama and, once again, he ran into Vyrypayev. He confessed to journalists that he had taken a fancy to the play The Drunks for its originality and rarity, for the possibility to look at man in a moment, when he/she feels to be both vulnerable and divine. "This is exactly a title which, on the one hand, is very powerful and addresses the quintessential challenges of human existence, while on the other hand, by its comic scenes, it has the potential to be attractive to the audience."17

It is a different type of dramatic text, in a sense, more traditional than July or Illusions. While the above plays are dominated by narrative principle, The Drunks is a play of diverse characters that interact and communicate, engage in dialogues,

${ }^{17}$ OPOLDUSOVÁ, J. Boh rozpráva ústami opitých [The Lord Speaks through the Mouth of Drunks]. In Pravda, Vol. 24, Issue 280, p. 43, 6 December 2016. 
philosophise and listen to other people's confessions. Everything takes place in a single evening, in a state of alcoholic stupefaction, when one throws away self-control and inhibitions and becomes more candid. Like in a film script, the author meticulously portrays the setting, situations, the physical action of characters. Like Illusions, the play was written by Vyrypayev on demand of a German theatre, therefore, characters do not have typical Russian names (though some, such as Mark, Roza, Max and Linda, are common in Russia). Although Vyrypayev claimed that when it comes to genre, the play Illusions was a comedy, Kudlác opted for staging it as a serious dramatic piece and, conversely, although The Drunks were referred to as drama by Vyrypayev, Kudláč produced it as a clearly playful comedy with a philosophical overtone. In Žilina, the play and its protagonists were made significantly younger. In Vyrypayev's understanding, the age of his characters is between twenty and fifty plus years. However, Žilina drama ensemble consists of young actors, and so Kudláćs production featured mostly thirty-year-old actors (with the exception of an actor impersonating Mark, director of an international film festival). At the same time, the number of characters was reduced from fourteen to twelve (the characters of two young managers "disappeared"). The action on stage was electrifying and full of expressiveness, it maintained dynamic tempo and rhythm and the stage was packed with action. Some utterances were directly addressed to the audiences, as if urging them to a reflection or to a dialogue. An occasional pathos was swiftly compensated for by humour and tragicomic situations were created. The actors did not mimic the state of intoxication by using distorted articulation. Stage design helped create an impression of physical instability: there was a mattress $30 \mathrm{~cm}$ thick covering the stage which made walking for actors difficult. The main theme was desire for love and the search for divine essence in us and in the world. Theatre makers played with a statement that the Lord can speak through the mouths of the drunks. A dispute was triggered whether comicality exceeded an acceptable limit, thus suppressing the existential dimension of the text. Judging by the reaction of young audiences, one may assume that the presence of the philosophical stratum was perceived by them largely thanks to humour. Older viewers, however, were disturbed by accentuating comicality in the interpretation of The Drunks.

In 2016, the Russian playwright and poet again visited Slovakia. Every year in May, under the aegis of the Theatre Institute ${ }^{18}$, the New Drama Festival in Bratislava takes place. It is dedicated to the productions of national and of the world contemporary drama. Ivan Vyrypayev became the patron of the 12th edition of the festival. In his presence, a ceremonial presentation of the collection of five of his plays translated into Slovak took place: Valentinov den' [Valentine's Day], Kislorod [Oxygen], Genezis № 2 [Genesis 2], Tanec Deli [Dance Delhi], Pyanye [The Drunks]. ${ }^{19}$ In the programme booklet Vyrypayev approached the participants and visitors of the festival with an essay Dráma je umelecký druh, ktorý zaniká [Drama is a Type of Vanishing Art]. Its main message was an Aristotelian defence of drama as a specific type of literature, which is materialised through theatre. Vyrypayev formulated his current theatrical credo. He stressed

${ }^{18}$ Theatre Institute Bratislava is a budgetary organisation of the Ministry of Culture of the Slovak Republic.

${ }^{19}$ VYRYPAJEV, I. Hry [Plays]. Translated by Eva Maliti Fraňová, Romana Štorková Maliti. Bratislava : Divadelný ústav, 2016. 


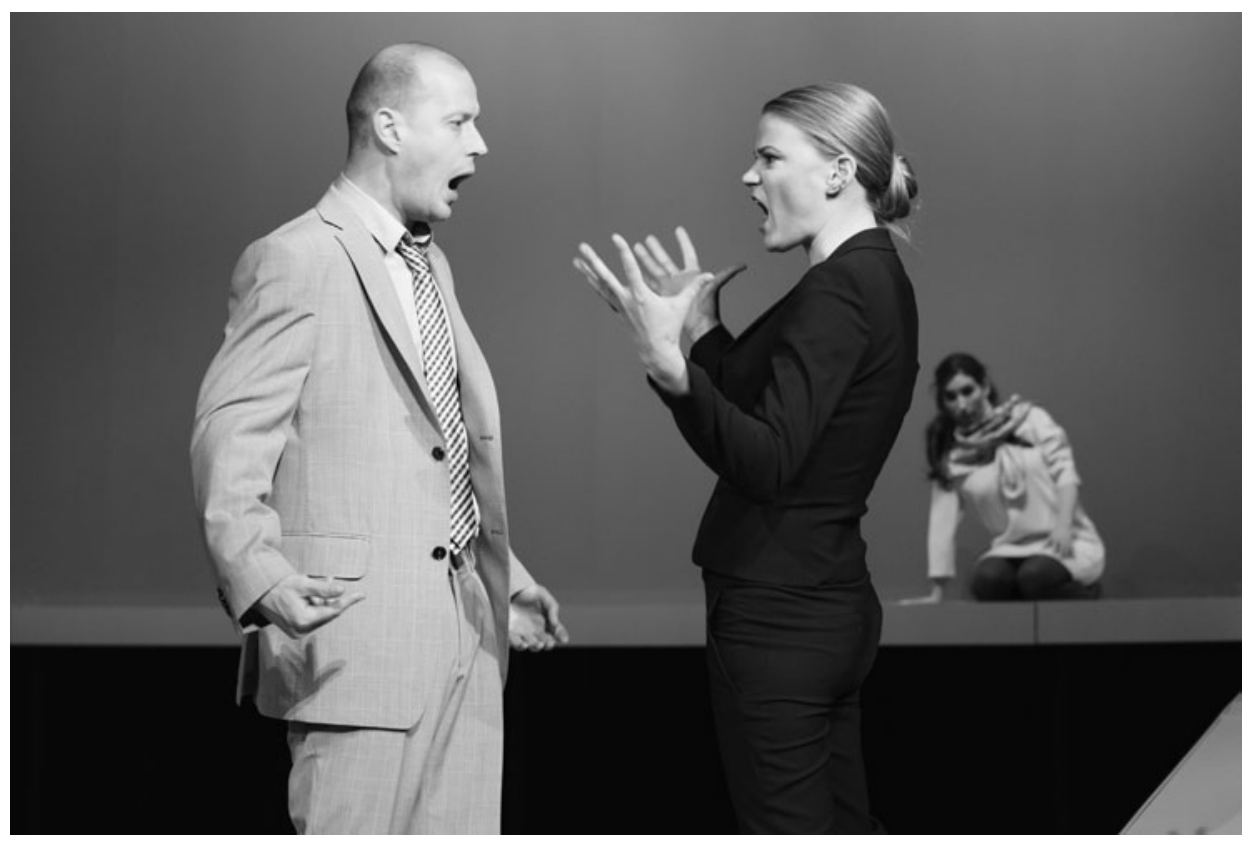

Ivan Vyrypayev: The Drunks. City Theatre Žilina, premiered on 5 December 2014. Braňo Bačo (Karl), Ivana Kubáčková (Lora), Kristína Sihelská (Linda). Direction Eduard Kudláč. Photo by Eduard Kudláč. City Theatre Žilina archives.

the playwright's supremacy over theatre makers. He opposed the idea of modern theatre directors tampering with other people's texts, modifying and adapting them to accommodate their individual intentions and fantasy. He claimed that "a good theatre play is in the first place a recommendation of the way of the existence on stage and of a method of communication with the audiences." ${ }^{20}$ It is an individualistic type of theatre, because theatre has always been shaped by the plays of good playwrights (e.g. Euripides, Goldoni, Chekhov, Ibsen, Brecht, Ionesco, etc). Ivan Vyrypayev insisted on returning to the dominance of playwrights and to showing respect for the play's text. The content and form of drama constitute unity, which should be binding on theatre directors. His critical view of contemporary theatrical practice and of drama suppression was verbalised in his lecture given at the festival. He warned that humanity "is losing one of the rarest types of art, the art of theatre play." 21

Only the future will tell how much these words are visionary. For the time being, despite the playwright's scepticism, there are still theatre professionals who with awe explore the secrets of a dramatic text. Alongside Eduard Kudláč, the young director Michael Vyskočáni showed great understanding for Ivan Vyrypayev's authorial style. In 2016/2017 theatre season, he became engaged in the notional Slovak-Russian

${ }^{20}$ VYRYPAJEV, I. Dráma je umelecký druh, ktorý zaniká [Drama as an Art Form that Becomes Extinct]. In NOVÁ DRÁMA/NEW DRAMA FESTIVAL. 9-13 May 2016. Bratislava, $12^{\text {th }}$ edition [programme booklet]. Bratislava : Divadelný ústav, 2016, p. 4.

${ }^{21} \mathrm{Ibid}$, p. 6. 
theatrical dialogue and in Ján Palárik Theatre in Trnava he staged the play Letniye osy kusayut nas dazhe v noyabre [Summer Wasps Bite Us Even in November]. ${ }^{22}$ Vyskočáni belongs to theatre professionals who favour current topics and modern drama. His productions are based on a thorough analysis of the text and on a partnership with the actor. Together they unravel the motives of characters, draw the audience in their minds and feelings, they punchline words and actions. At the same time, following the stories of individuals, they strive to portray a repetitive, timeless model of human existence. An analytical approach to the text with particular emphasis on elaborate acting style were employed by Vyskočáni in Trnava staging of Vyrypayev's text.

The play Summer Wasps Bite Us Even in November is of a more intimate nature, with only three characters. A well-established married couple and their friend meet at a birthday party. Their conversation brings a detective plot, and despite their utmost effort at a confrontation with the testimonies of other (offstage) characters, they fail to convincingly prove who lies to whom, when and with whom, who cheats on who and whether at least someone from the crowd tells the truth. Trnava theatre makers situated the play in a small intimate theatre space. In the original text, a thirty-year-old woman is confronted with two sixty- or seventy-year-old males. Vyskočáni altered the situation, he reduced the big age difference between the woman and the men and unified the characters' age span between 30 and 40 years, bringing the characters closer generation-wise. One of the play's riddles is the fact that the characters in their mutual communication would use the names Sára, Robert, Donald, while in the text, Vyrypayev consistently refers to them using different names - Elena, Mark, Jozef. By doing so, he questions their words, action, and even their identities, thus enhancing the theme of deception and the relativity of truth. Trnava theatre makers decided to bypass this puzzle, so as not to mislead the audience, therefore, on the stage and in the programme booklet the characters would be named Sára, Robert and Donald. However, the theme of false identity has been preserved in a different way. Throughout almost the entire performance the red-haired beauty Sára is seen as a brunette femme fatale and with the production drawing to a close, she removes a black wig from her head and shows the natural colour of her hair. Though extravagant at first glance, she has the manners of a very friendly hostess and is a perfect mysterious woman. No less extravagant is the sterile interior appointment of her house. It gives a feeling of oddness, which is enhanced by a passage from the mesmerising song Fifteen Feet of Pure White Snow by Nick Cave which frames the entree and the finale of the production. Vyskočáni works with the text like with a light intellectual psychoanalytical causerie, with accurately hit forehands, responses, and punch lines. At the same time, everything remains absurd, relative and incognizable, simply, Edward Albee hyperbolised. "Manipulative psychological games" ${ }^{23}$ the characters play with each other are their life rituals. The interpretive key to Trnava staging was a creative gesture which may be referred to as the acting of concealed truth. The students of Trnava secondary schools and colleges were so deeply impressed by the production about an eternal lie of life, which, however, failed to smother human yearning for love and truth that in June 2018, they awarded it a prize for the best production on the cur-

\footnotetext{
${ }^{22}$ Premiered on 8 April 2017.

${ }^{23}$ GALDÍKOVÁ, L. Bolestivé štípance na duši [Painful Stings on Soul]. In kød, 2017, Vol. 11, Issue 6, p. 92 .
} 


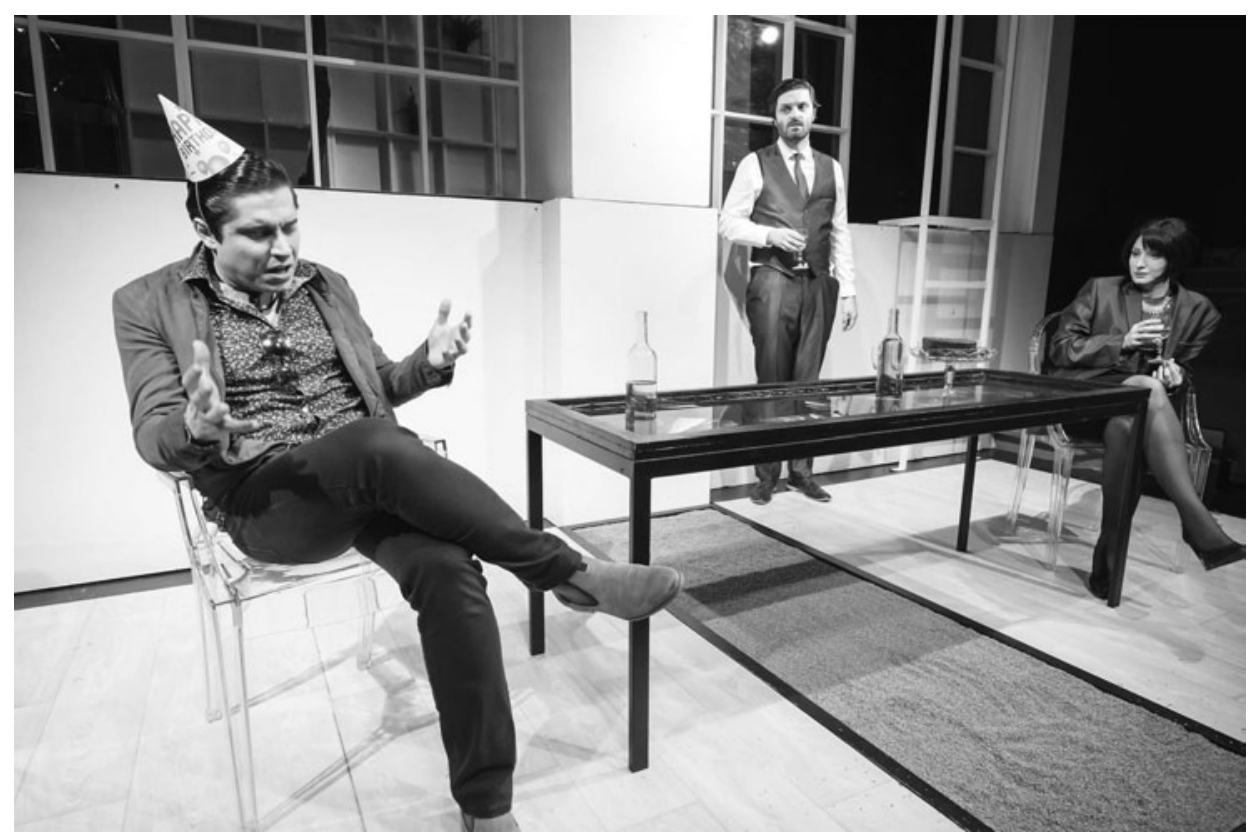

Ivan Vyrypajev: Summer Wasps Bite Us Even in November. Ján Palárik Theatre in Trnava, premiered on 8 April 2017. Martin Križan (Donald), Tomáš Vravník (Robert), Katarína Šafaříková (Sára). Direction Michael Vyskočáni. Photo by René Miko. Ján Palárik Theatre in Trnava archives.

rent repertory of Ján Palárik Theatre in Trnava. Once again, Ivan Vyrypayev's play directed by Michael Vyskočáni worked as the generational narrative.

It was again Eduard Kudláč to have reached out for Ivan Vyrypayev's text when he staged his play Nevynosimo dolgiye obyatiya [Unbearably Long Embraces] (premiered on 2 October 2017), together with four actors of the City Theatre Žilina. He needed an intimate space, which would tally with unravelling the intimate world of four characters and their communication with the universe. In line with his initial intent, Kudláč deliberated locating the production in a former synagogue, where rehearsals had taken place. The idea was never materialised due to technology concerns (there was a problem with the acoustics and with the manner of sound propagation which disrupted the principle of intimacy in the communication with the audience and between the characters), which made the director move the production back to the theatre. At the same time, he communicated his ambition to hunt for alternative non-theatrical spaces whenever touring, as he refused to take advantage of a big stage of the City Theatre Žilina and opted for a small studio stage instead. He removed the conventional division of space between the stage and the auditorium, which reduced the number of visitors who were seated in a circle and in its centre, a peculiar piece of art was mounted dominating the scenic design concept. His understanding of scenic design invited loose associations. For someone, it was just a heap of star dust that resonated with the theme of the universe and of transcendence. For others, the dazzling white particles of an unknown matter epitomised the fragments of broken 


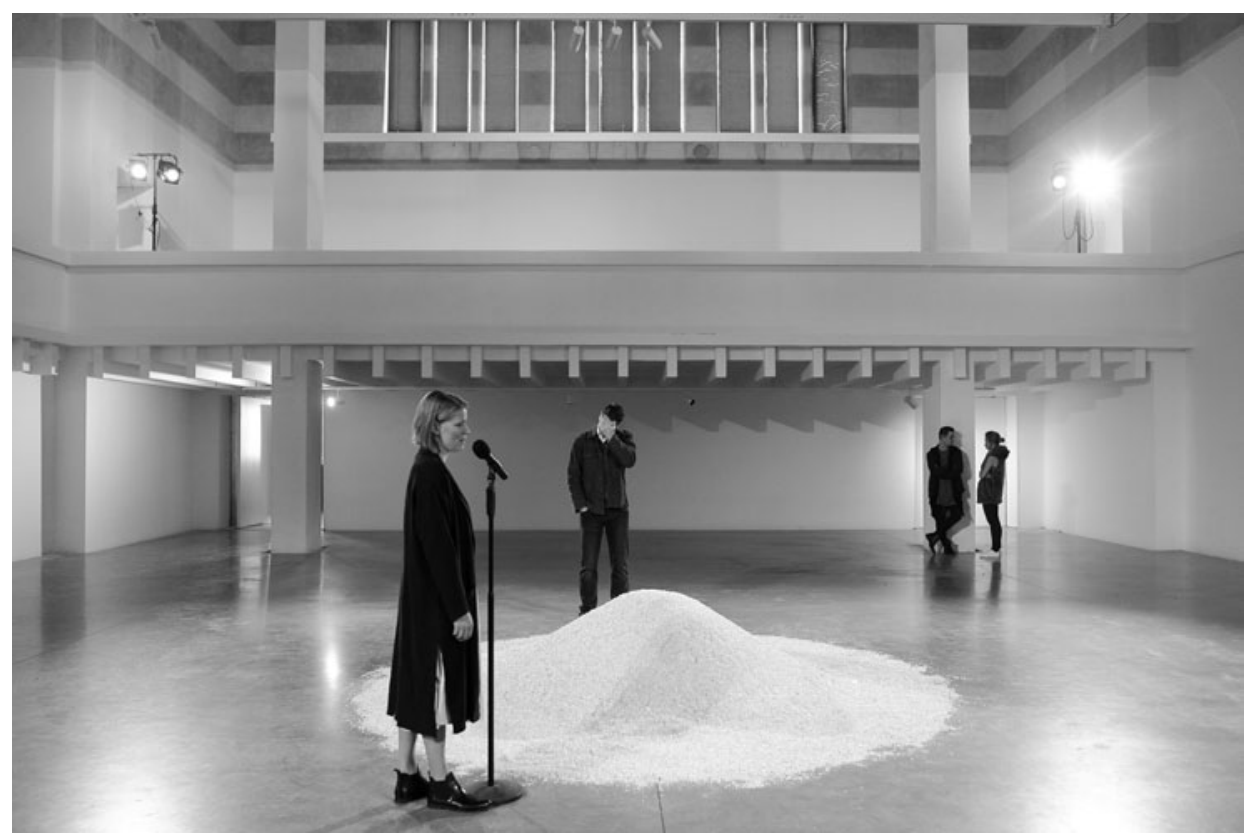

Ivan Vyrypayev: Unbearably Long Embraces. City Theatre Žilina, premiered on 2 October 2017). Ivana Kubáčková (Monika), Ján Dobrík (Charlie), Michal Tomasy (Kryštof), Iveta Pagáčová (Emmy). Director Eduard Kudláč. Photo by Robert Tappert. City Theatre Žilina archives.

feelings, hopes and relationships, the ruins of human emotions. Four actors moved in the circle around this object, surrounded from all sides by the audience. They impersonated thirty-year-olds, ordinary citizens of today's cosmopolitan world, freely travelling between New York and Berlin, between America, Europe and other continents. On their travels around the world they all, the Pole Monika and her husband Charlie, the Czech man Kryštof and New Yorker Emmy, realise a need to hunt for the purpose of life.

In the play Unbearably Long Embraces Vyrypayev, once again, took advantage of the narrator principle. Unlike July and Illusions, the distance between the actor and the character was reduced. It is no longer an actress interpreting the story of a killer, a man or a woman talking about the life illusions of old married couples. This time, it is Monika, Emmy, Charlie and Kryštof narrating her/his own story. Their confessions are highly intimate, they are often made in the third person, part of their " $\mathrm{I}$ " engages in a dialogue with the universe. They confess to their sexual practices, to infidelity, abortion, self-inflicted miseries, and to destructive desolation, which they crave to overcome and to find support and love in something beyond themselves. The words put in their mouths by the author, flow like a torrent, and they demonstrate the quality of good writing. The almost naturalistic stories of everyday life are associated by Vyrypayev with a spiritual content, with immersions into the symbolic visions of individuals. Four young Žilina actors proved outstandingly successful in coping with the complex text. As noted by the critic Martina Ulmanová, notwithstanding a deep inner engagement, the actors kept their facial expressions under control, "their elo- 
cution is generally matter-of-fact and rational, and it only becomes more imperative when reaching out for the microphone, to whisper the most intimate feelings of their characters. “24 It was the brilliant performance of actress Ivana Kubáčková of the levelled quartet that came to the fore in her rendition of Monika who "almost in a civil way presented the excruciating pain of deprivation and the relationship tribulation" 25 and, at the same time, "she was able to interpret Vyrypayev touching infinity." ${ }^{26}$ Characters moved slowly in the acting space like in a vicious circle of a mistaken, broken, and empty life, from which there is no way out. Ritual slowness, walking around the centre, and repeated refrains added a meditative dimension to the production.

In their third encounter with the creation of Ivan Vyrypayev, Zilina theatre professionals capitalised on their prior experience and demonstrated their determination to work hard, to suggestively interpret the play. They adopted Vyrypayev's concept of theatre as a communication challenge to establish a dialogue with the viewer, to raise fundamental questions and to trigger self-reflection. The texts of the Russian playwright enabled Eduard Kudláč to realize his concept of theatre as a philosophical statement containing aesthetic values. The productions Illusions (Slovak National Theatre) and Unbearably Long Embraces are among the masterpieces of Kudláčs art of direction.

\section{Conclusion}

When a question is asked whether it makes any sense for Slovak theatre to produce Ivan Vyrypayev's plays and whether one can talk about a more profound impact of his work on Slovak theatre, several possible answers crop up. In recent years, Vyrypayev has become the best known and most frequently staged contemporary Russian playwright in Slovakia. It is his creation through which our theatre has revived its active relationship with Russian culture and with the so-called new Russian drama. It is important to note that this relationship is now liberated from the heritage of "Sovietism" and it develops on new foundations. It is not no longer an involuntary dictate of "Big Brother" over a small and politically subordinate culture. It has become an inspiring alliance which helps refine mastery and develop modern techniques of direction, acting, and drama. It allows theatre professionals to establish a dialogue with the viewers in a unique way, to talk with them about the present by raising eternal and timeless topics, while this engaging discourse is free from postulations and didacticism. Initially, Vyrypayev's plays reached the Slovak theatre through the youngest generation of theatre professionals. Fifteen years on, his poetics appeals to both young artists and reputable masters, the legends of Slovak acting. After the staging of six Vyrypayev's plays by the Slovak theatres, it is very likely that more productions of his plays will follow.

${ }^{24}$ ULMANOVÁ, M. Dotyky a spojenia: to najlepšie podl’a KLMKRx [Touches and Connections Theatre Festival: The Very Best According to KLMKRx]. In kød, 2018, Vol. 12, Issue 7, p. 24.

${ }^{25}$ BALLAY, M. Neznesitel'ná prítomnost' [The Unbearable Present]. In kød, 2018, Vol. 12, Issue 1, p. 28.

${ }^{26}$ ULMANOVÁ, M. Neznesitelne dlhé objatia. Kritická platforma festivalu Dotyky a spojenia [Unbearably Long Embraces. A Critical Platform of Touches and Connections Theatre Festival]. In kød, 2018, Vol. 12, Issue 7, p. 17. 
The study is an output of the SRDA project No. 15-0764, Slovak Theatre and Contemporary European Theatre Culture, Continuity and Discontinuity.

\section{Translated by Mária Švecová}

\section{LITERATURE}

BALLAY, Miroslav. Neznesitel'ná prítomnost' [The Unbearable Present]. In kød, 2018, Vol. 12, Issue 1, pp. 25 - 28.

BEŇOVÁ, Juliana. Ako v Žiline podl’ahli ilúziám [How People in Žilina Give into Illusions]. In Monitoring divadiel na Slovensku, 23 April 2016. [online]. [cit. 12 April 2019]. Available at: https://www.monitoringdivadiel.sk/recenzie/recenzia/ako-v-ziline-podlahli-iluziam/. ISSN 2454-0129.

BEŇOVÁ, Juliana. Všetci o tom chceme hovorit', ale nik nemá odvahu [We All Want to Talk about It, But No One Has the Courage]. In kød, 2014, Vol. 8, Issue 3, pp. 10 - 17. ISSN 13371800.

GALDÍKOVÁ, Lucia. Bolestivé štípance na duši [Painful Stings on Soul]. In kød, 2017, Vol. 11, Issue 6, p. 92. ISSN 1337-1800.

HEVIER, Daniel. Ked’ sa žije z ilúzie [When People Live on Illusion]. In Sme, Vol. 22, Issue 23, p. 12, 29. January 2014. ISSN 1335-440X.

MOŚKO, Matej. Symbolika na premýšlanie. Ivan Vyrypajev: Júl. [Symbolics to Think about. Ivan Vyrypayev: July.] In Monitoring divadiel na Slovensku, 29 March 2010. [online]. [cit. 11 April 2019]. Available at: https://www.monitoringdivadiel.sk/recenzie/recenzia/symbolika-na-premyslanie/. ISSN 2454-0129.

OPOLDUSOVÁ, Jena. Boh rozpráva ústami opitých [The Lord Speaks through the Mouth of Drunks]. In Pravda, 2016, Vol. 24, Issue 280, p. 43, 6 December 2016. ISSN 1335-4051.

POLÁK, Milan. Diváka vtiahli na javisko [The Viewer Was Drawn onto Stage]. In Literárny týždenník, 2014, Vol. 27, Issue 5 - 6, p. 7, 12 February 2014. ISSN 0862-5999.

TARBAJOVSKÁ, Lucia. Ivan Vyrypajev: Júl [Ivan Vyrypayev: July]. In Vlna, 2011, Vol. 13, Issue 48, pp. 156 - 177. ISSN 1335-969X.

ULMANOVÁ, Martina. Dotyky a spojenia: to najlepšie podla KLMKRx [Touches and Connections Theatre Festival: The Very Best According to KLMKRx]. In kød, 2018, Vol. 12, Issue 7, pp. 23 - 29. ISSN 1337-1800.

ULMANOVÁ, Martina. Neznesitelne dlhé objatia. Kritická platforma Dotyky a spojenia [Unbearably Long Embraces. A Critical Platform of Touches and Connections Theatre Festival]. In kød, 2018, Vol. 12, Issue 7. p. 17. ISSN 1337-1800.

VANNAYOVÁ, Martina. Sny betónových sídlisk [The Dreams of Concrete Housing Estates]. In Divadlo v medzičase, 2004, Vol. 9, Issue 1 - 2, p. 6. ISSN 1335-9355.

VYRYPAJEV, Ivan. Dráma je umelecký druh, ktorý zaniká [Drama as an Art Form that Becomes Extinct]. In NOVÁ DRÁMA/NEW DRAMA FESTIVAL. 9 - 13 May 2016. Bratislava, $12^{\text {th }}$ edition [programme booklet]. Bratislava : Divadelný ústav, 2016, pp. 4-6.

VYRYPAJEV, Ivan. Hry [Plays]. Translation by Eva Maliti Fraňová, Romana Štorková Maliti. Bratislava : Divadelný ústav, 2016, 270 p. ISBN 978-80-89369-95-9.

VYRYPAYEV, Ivan. Открытое письмо драматурга и режиссера Ивана Вырыпаева в подлержку Кирилла Серебренникова [An open letter of playwright and stage director Ivan Vyrypayev in support of Kiril Serebrennikov, 25 August 2017]. [online]. [cit. 10 May 2019]. Available at: https://telegra.ph/Otkrytoe-pismo-dramaturga-i-rezhissera-Ivana-Vyrypaeva-v-podderzhku-Kirilla-Serebrennikova-08-24.

VYRYPAYEV, Ivan. Пьесы [Plays]. Moskva: Tri Kvadrata, 2018, 557 p. ISBN 978-5-94607-209-0]. 
VYRYPAYEV, Ivan - CHERNYAKOVA, Sasha. Все мои пьесы очень русские [All my plays are very specific to Russian society, an interview, 11 December 2018]. [online]. [cit. 20 May 2019]. Available at: https://snob.ru/entry/169432.

VYRYPAYEV, Ivan - VERESKOV, Sergey. В России люди приходят в театр за смыслом жизни [In Russia, people seek purpose of life in the theatre, an interview, 1 December 2018]. [online]. [cit. 11 May 2019]. Available at: https://www.elle.ru/celebrities/interview/ivan-vyrypayev-v-rossii-lyudi-prihodyat-v-teatr-za-smyslom-zhizni-id6801722/.

VYRYPAYEV, Ivan - IVANOVA, Olga. Я ничего не могу попросить у Бога, потому что я считаю, что его нет [I cannot ask God for anything, as to my mind he does not exist. 15 December 2014]. [online]. [cit. 20 May 2019]. Available at: https://okolo.me/2014/12/ya-nichego-ne-mogu-poprosit-u-boga-potomu-chto-ya-schitayu-chto-ego-net/.

ZWIEFELHOFER, Miroslav. Júl Ivana Vyrypajeva - dráma vraha Piotra alebo výstup jednej herečky? [July by Ivan Vyrypayev - the Drama of the Murderer Piotr or a Performance of an Actress?] In kød, 2010, Vol. 4, Issue 5, pp. 17 - 20. ISSN 1337-1800.

\author{
Nadežda Lindovská \\ Ústav divadelnej a filmovej vedy CVU SAV \\ Dúbravská cesta 9 \\ 84101 Bratislava \\ Slovakia \\ e-mail: nadiali@mail.ru
}

